ISSN: 2146-3042

DOI:

\title{
Endüstri Mühendisliği Öğrencilerinin Maliyet Muhasebesi Dersine Ve Dersi Veren Öğretim Üyesine Yönelik Algıları*
}

\author{
Metin ÇALIK** \\ Barış DEMİRCI*** \\ Tunga BOZDOĞAN****
}

\begin{abstract}
ÖZET
Bu araştırmanın temel amacı, pandemi süreci gibi zorlu bir ortamda öğrenme uyarımının oluşturulmasında, endüstri mühendisliği ögrencilerinin maliyet muhasebesi dersine ve dersi veren ögretim üyesine yönelik algılarının tespit edilmesi ve bu algılar arasındaki ilişkinin ortaya konulmasıdır. Bu çalışmayı özelikle literatürdeki çalışmalardan ayıran farklılı̆̆ doğrudan muhasebe ile ilgili olmayan bir bölümde ve daha önceden alışılmamış bir öğrenme ortamında ögrencilerin derse ilişkin algılarının değerlendirilmesinin amaçlanmasıdır. Araştırma evrenini Kütahya Dumlupınar Üniversitesi Mühendislik Fakültesi Endüstri Mühendisliği bölümünde maliyet muhasebesi dersini alan öğrencileri oluşturmaktadır. Çalışmada 2020 yılında kolayda örnekleme yöntemine göre 139 öğrenciden anket tekniğiyle veri toplanmış ve toplanan veriler güncel istatistik programında analiz edilmiştir. Buna göre maliyet muhasebesi dersi alan endüstri mühendisliği öğrencilerinin dersi veren ögretim üyesine yönelik algıları ile derse ilişsin algıları arasında istatistiksel olarak anlamlı bir ilişki olduğu tespit edilmiştir.
\end{abstract}

Anahtar Kelimeler: Algı, Maliyet Muhasebesi, Endüstri Mühendisliği, Muhasebe Eğitimi, Yetkinlik.

JEL Sinıflandırması: M41, M49.

The Perceptions of Industrial Engineering Students about Cost Accounting Course and the Lecturer of Cost Accounting Course

\section{ABSTRACT}

The main purpose of this study is to determine the perceptions of industrial engineering students regarding the cost accounting course and the contribution of the faculty's attitude to learning in creating a learning stimulus in a challenging environment such as a pandemic process. The difference between this study and especially the studies in the literature is that it aims to evaluate students' perceptions about the course in a department that is not directly related to accounting and in a previously unconventional learning environment. The population of the research consists of the students who take the cost accounting course at the Department of Industrial Engineering, Faculty of Engineering, Kütahya Dumlupinar University. In the study, using the questionnaire method, it was tried to determine how successful the perceptions of industrial engineering students are in increasing their learning levels. Within the framework of the results obtained from the study, it was determined that there is a meaningful relationship between the perception of the instructor about the course process and the students' perception of the course.

Keywords: Perception, Cost Accounting, Industrial Engineering, Accounting Education, Competence.

Jel Classification: M41, M49.

\footnotetext{
* Bu makale, 23-25 Nisan 2021 tarihleri arasında gerçekleştirilen VI. Uluslararası Muhasebe ve Finans Sempozyumunda bildiri olarak sunulmuştur. Makaledeki anket çalışmasının, Kütahya Dumlupınar Üniversitesi Sosyal ve Beşeri Bilimler Araștırma ve yayın Etiği Kurulu'nun 21.01.2021 tarihli 2021/01 sayılı toplantısında, etik açıdan uygun olduğuna karar verilmiştir.

Makale Gönderim Tarihi: 09.06ç2021, Makale Kabul Tarihi: 18.07.2021, Makale Türü: Nicel Araştırma ** Dr.Öğr.Üyesi, Kütahya Dumlupınar Üniversitesi, Kütahya Sosyal Bilimler Meslek Yüksekokulu, metin.calik@dpu.edu.tr, ORCID: 0000-0001-6059-5454.

*** Dr.Öğr.Üyesi, Eskişehir Osmangazi Üniversitesi, Turizm Fakültesi, bdemirci@ogu.edu.tr, ORCID: 00000002-1247-1841.
}

**** Doç.Dr. Eskişehir Osmangazi Üniversitesi, İktisadi ve İdari Bilimler Fakültesi, tunga.bozdogan26@gmail.com, ORCID ID: 0000-0002-1651-9865. 


\section{GİRIŞ}

Muhasebe eğitimi araştırmaları, genellikle öğrenci çıktıları ve mesleki yönelimin yetkinlikle ilişkili faktörlerin anlaşılmasını geliştirmek amacıyla yapılan çalışmalardır. $\mathrm{Bu}$ çalışmaların önemli bir boyutu da öğrencilere bilgi aktarımını geliştirmek için profesyonel ve akademik eğitim arasındaki boşluğun ele alınmasıdır. Ayrıca herhangi bir muhasebe eğitimi araştırmasında araştırmacının, yapılan araştırmanın muhasebe öğrenen öğrencilere nasıl fayda sağlayacağ 1 ve diğer muhasebe eğitimcilerinin neden bu çalışmayla ilgilenmesi gerektiği sorularını kendilerine sormaları yargısından hareket edilmesi de ayrı bir gereklilik olmaktadir.

Yükseköğretimde muhasebe öğretimine ilişkin, derslerin öğrencilerin iletişim, analitik, yansıtıcı ve eleştirel düşünme becerilerini geliştirmesinin sağlanması rolü konuları önemli ölçüde ilgi çekmektedir (Mourik ve Wilkin, 2019: 312). Öğrenme ve düşünme becerilerinin ve yetkinliklerinin kazanılması, muhasebe eğitiminin birincil amacı haline gelmiştir. Çalışmaları hakkında aldıkları geri bildirimlerden öğrencilerin memnuniyetsizliği, çoğu kurumun, öğrenci iş yükünde önemli artışlar olmadan ele almak istediği bir konudur (Ferrell, 2012:3).

Muhasebe eğitiminde, öğretim stratejileri etkili bir şekilde kullanılırsa, eğitimciler muhasebe bilgisi edinimini ve akademik performans1 artırabilirler (Sithole, 2017: 2). Eğitim literatüründe, öğrenme yaklaşımları paradigması, öğrenmenin kalitesini sistematik olarak iyileştirmek için öncelikle öğrencinin öğrenme sürecini anlamasının gerekli olduğunu savunmaktadır. Öğrenci öğrenme yaklaşımlarının, akademik performans ve eğitim deneyiminden memnuniyet gibi faktörlerden etkilenen öğrenci öğrenmesinin kalitesini belirlemede çok önemli olabileceğini göstermektedir (Booth vd.,2010: 277). Bu durum, dijitalleşme ve pandemi gibi beklenmedik gelişmeler göz önüne alındığında eğitim sürecinin sürekli ölçülmesi, değerlendirilmesi ve geliştirilmesi gerekliliğini bir kat daha arttırmaktadır. Günümüzde işverenler üniversitelerin öğrencileri işgücünün yetkin üyeleri olmaya hazırlaması gerektiğine inanırken, çoğu akademisyen üniversitelerin öğrencilerin entelektüel yeteneklerini ve 'uygunluk ve geleneğe meydan okuma' ve 'kendileri için düşünme' becerilerini geliştirmede kilit bir role sahip olduğunu düşünmektedirler (Bui ve Porter, 2010: 24).

Mesleki yetkinlik, belirli bir mesleğin üyesi olmanın özü olarak görülen bir dizi özelliği taşıma olarak ifade edebilir. Bu özellikler bilgi, tutumlar ve bazen bedensel görünümü içerebilir ancak bunlarla sınırlı değildir (Guo, 2018: 22). Bireylerin kendilerini belirli bir grubun "içinde" veya "dışında" olarak algılamaları mesleki kimliklerinin çerçevesini belirleyen önemli bir unsur olmaktadır (Halbert vd., 2020: 2). Mesleki kimliğin içsel yönü, bireylerin kim olduklarına ilişkin "özel kavramları" ile ilgilidir. Mesleki yetkinlikte mesleki kimliğe dönük özel kavramların edinimiyle oluşabilmektedir. Geleceğin maliyet muhasebecilerine, kuruluşlarının başarılı olmasını sağlayıcı stratejileri formüle etme, analiz etme ve yürütmeye yardımcı olma profiline sahip etkili yöneticilerin iş ortaklığ rolünü yansıtıcı yetkinlikler kazandırılmalıdır. 
Maliyet muhasebesi söz konusu olduğunda, bir endüstri mühendisi tarafindan sahip olunan, aynı zamanda bir meslek kuruluşunun üyeliğiyle uyumlu olan teknik yeteneklere, değerlere, davranışlara ve eğilimlere dâhil edilerek bir iç kimlik oluşturulabilir. İşyerinde sosyalleşme ve aşinalık terimleri, bir işyeri kimliğinin geliştirilmesinin, belirli bir zihniyetin veya üniversitenin verdiği istihdam edilebilirlik referanslarının elde edilmesi kadar bir değişim süreciyle ilgili olduğu da ayrıca ileri sürülebilmektedir (Halbert vd., 2020: 2). Birinin ne olacağı ile ilgili gelecekte olması beklenenler, mesleki kimlik açısından da aynı derecede önemlidir. Meslek hayatında devamlılık beklentisi vardır. Bu anlamda profesyonel kimlik, hem "yaşanmış deneyim" hem de "beklenen deneyim" olarak görülebilecek yaşam yolculuğudur (Guo, 2018: 21). Mesleki uygulamada üst düzey düşünme becerilerinin önemi, eğitimcileri daha üst düzey düşünme becerilerini öğretmeye odaklanmaya yönlendirmiştir. Örneğin, mühendislik gibi hızla değișen alanlarda, ağırlıklı olarak olgusal bilgilerin öğretilmesine yapılan vurgu, bu becerileri öğretmeye doğru kaymıştır.

\section{ENDÜSTRİ MÜHENDİSLİĞİ BÖLÜMÜ AÇISINDAN MALIYYET MUHASEBESİ BİLGISININ ÖNEMI}

Mühendislik fakültelerinde bir bölüm olarak yer alan endüstri mühendisliği, mal ve hizmetlerin verimli bir şekilde üretilmesini sağlamak için insanları, malzemeleri, bilgileri, enerjiyi ve ekipmanları içeren sistemlerin iyileştirilmesi, tasarımı ve kurulumuna yönelik teknik ve ilkelerin uygulanması olarak tanımlanmaktadır (Rao ve Srivastava, 2019: 2). Henry Towne'in 1886'da ASME (American Society of Mechanical Engineers) toplantisinda ifade edilen fikirlerinden ortaya çıkan endüstri mühendisliğinin görevleri ve eğitiminin bir parçası olarak üretim maliyetlerini azaltma kararı vermek için maliyet bilgilerinin kullanılması yer almaktadır (AACE, 2021).

Endüstri mühendisliği özelikle işçilik maliyetlerini üretim için planlanan her iş için gerekli planları yapmaktadır. Üretim işletmelerinde endüstri mühendisliği departmanı, şartnameler hazırlayarak, güvenli ve verimli çalışma koşullarını koruyarak, araştırma ve geliştirme faaliyetlerini başlatıp denetleyerek, yöntem etüdü, hareket etüdü yaparak çalışma koşulları, üretim yöntemleri, iş performansları üzerinde kontrolün sürdürülmesine önemli düzeyde yardımcı olmaktadır. Ayrıca işgücü maliyetlerini azaltmaya yönelik olarak; zaman etüdü, parça oranlarını belirleme, iş değerlendirmesi yapma, liyakat değerlendirmesi ve iş analizi yapma, işgücü verimliliğini ölçme ve genel olarak işgücü verimliliğini/üretkenliğini artırma görevleri arasındadır (ICAI, 2018: 74).

Uygulamada, endüstri mühendisliği, planlama ve kontrol yöntemlerini ve verilerini geliştirmek için kaynak kullanımı çalışmasıdır. Kaynak kullanımı, kaynak birimleri ve para değerleri olarak muhasebeleştirilir. Bu anlamıyla maliyet muhasebesi, kaynak kullanımının ölçülmesinde, değerlendirilmesinde, analiz edilip geliştirilmesinde her türlü organizasyonda en önemli bilgi sistemlerinden birisidir. 


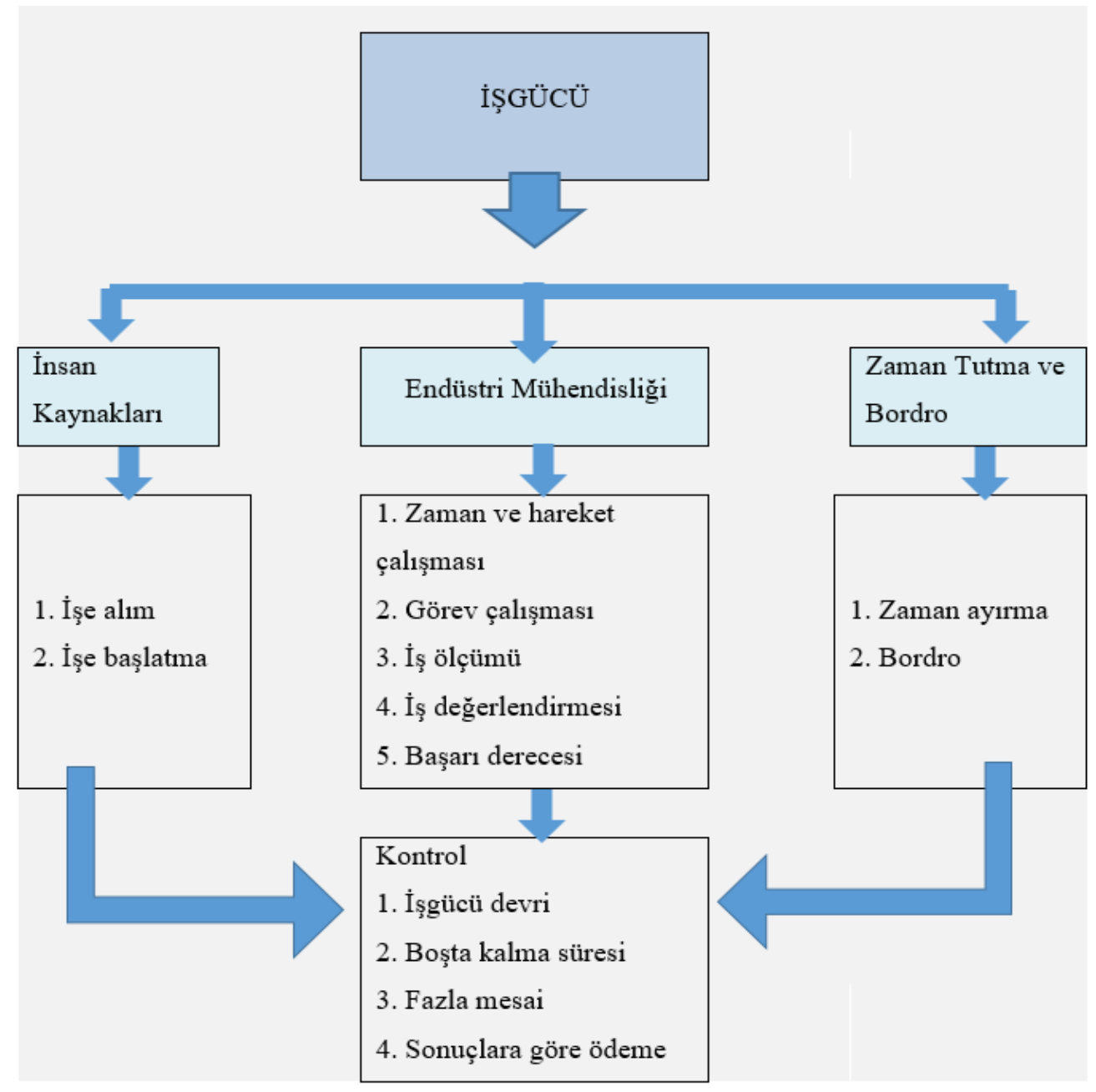

Şekil 1. İşçilik Maliyetlerinin Değerlemesinde Endüstri Mühendisliğinin Rolü Kaynak: (ICAI, 2018)

Yukarıda Şekil 1.'de endüstri mühendislerinin iş yaşamında işçilik maliyetlerine ilişkin ölçüm ve değerleme görev dağılımı yer almaktadır. Bu işlemler maliyet muhasebesi ders içeriğinde yer alan işçilik maliyet davranışı, işçilik maliyetlerinin belirlenmesi ve ölçülmesi konularını kapsamaktadır.

Yükseköğretim Kurulu'na bağlı üniversitelerin, 50'si Devlet, 43'ü Vakıf, 3'ü KKTC ve 1'i Kazakistan'da olmak üzere toplam 95'inde Endüstri Mühendisliği Bölümü bulunmaktadır. 2021 yılı başı itibariyle, Yükseköğretim Kurulu Başkanlığı’nın Tez Merkezi verilerinden Endüstri Mühendisliği Bölümü lisansüstü öğrencilerinin 2000-2021 yıllar1 arasında Endüstri Mühendisliği Yüksek Lisans öğrencileri toplam 3892 adet yüksek lisans tezinin 49 tanesi,705 adet doktora tez çalışmasının 8 tanesi maliyet muhasebesi alanında hazırlanarak onaylanmıştır (Ulusal Tez Merkezi, 2021). Bu durum maliyet muhasebesi dersinin Endüstri Mühendisliği Bölümü öğrencileri açısından tüm öğretim (lisans, yüksek lisans, doktora) kademelerinde olduğu gibi akademik kariyer açısından da çok önemli bir alan olduğunu göstermektedir. 


\section{LITERATÜR}

Literatür taramasında iki aşamalı bir strateji geliştirilmiştir. İlk olarak, muhasebe eğitimine ilişkin yapılan akademik çalışmaların sınıflandırılmasına odaklanılmıştır. Daha sonra ise çalışmanın ana temasını oluşturan öğrencilerin derse ilişkin algılarına ve öğreticinin derse ilişkin algılarıyla ilgili yapılan çalışmalar incelenmiştir.

Apostolou vd. (2016) tarafından yapılan muhasebe eğitimine ilişkin yapılan literatür çalışmaları dört başlıkta; betimleyici (mantık veya anekdot deneyimlerinden çıkan sonuçları tartışan makaleler), ampirik tanımlayıcı (sonuçların bir veri analizinden türetildiği makaleler), öğretim kaynağı (içeriğin hem öğretilmesini hem de öğrenilmesini kolaylaştırabilecek özel bir stratejileri içeren makaleler) ve vakalar (öğrencilerin karmaşık konuları anlamalarına yardımcı olmayı amaçlayan bir görev veya ödevi izleyen gerçek veya varsayımsal bir bilgi kümesi sağlayan makaleler) biçiminde Şekil 2'de sınıflandırılmıştır.

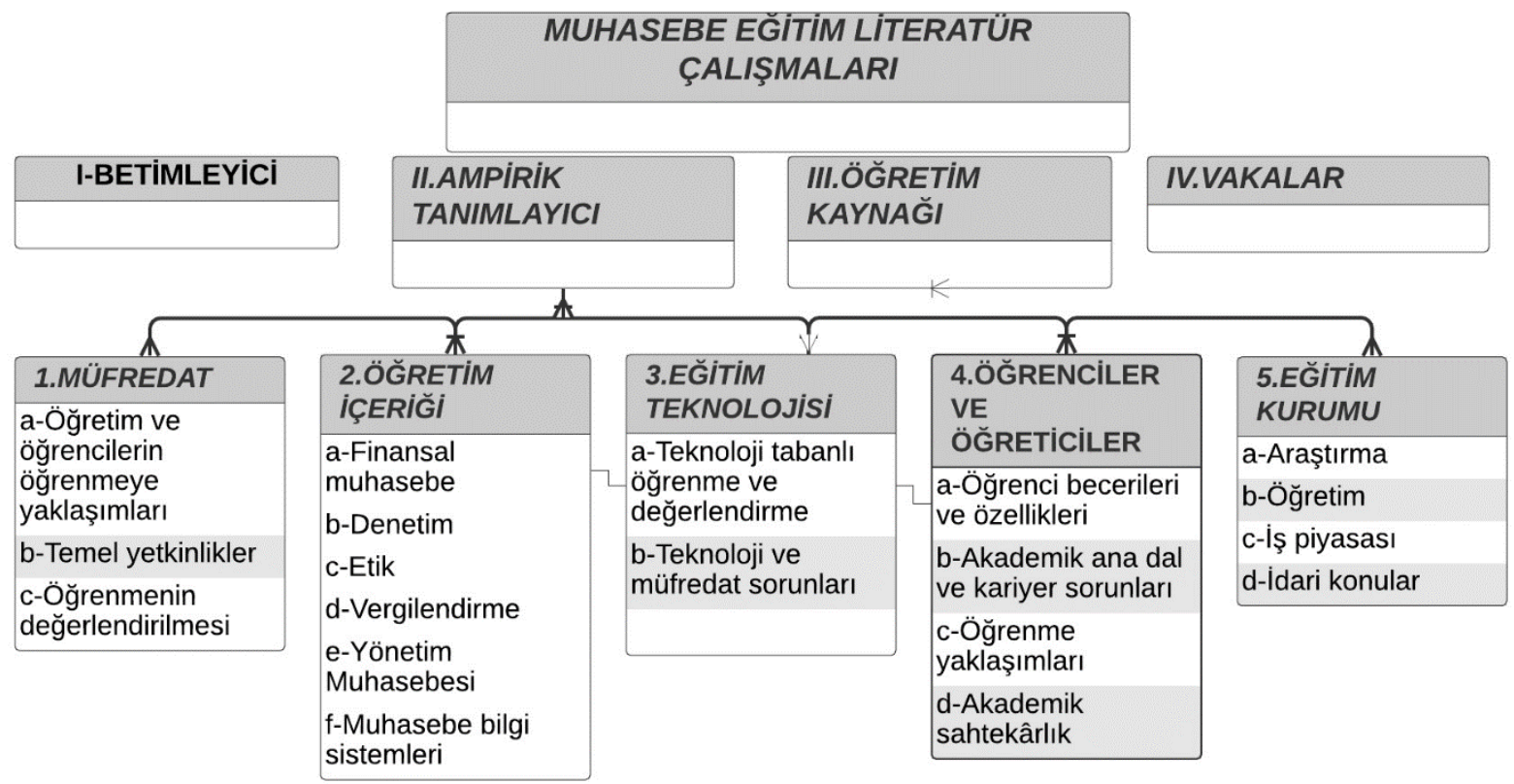

Şekil 2. Muhasebe Eğitim Literatürü

Kaynak: Apostolou vd. (2016)'den derlenmiştir.

Muhasebe eğitimi literatür incelemelerinin sınıflandırılmasında yer alan ampirik makaleler de kendi içerisinde; müfredat konuları, öğretim içeriği, eğitim teknolojisi, öğrenciler ve öğretim üyeleri; eğitim kurumu olmak üzere beş alt kategoriye ayrılmıştır. Literatürde yayınlanan ampirik makalelerde yazarlar coğrafi konum bilgilerini rapor etmektedirler. Coğrafi bilgi, karşılık gelen kültürel çıkarımlarla birlikte, bulguların genelleştirilmesinde veya kontrol değişkenleri olarak kullanım için araştırma sonuçlarının tartışılmasında önemlidir.

Müfredat kategorisinde a-Öğretim ve öğrencilerin öğrenmeye yaklaşımları; b-Temel yetkinlikler ve c-Öğrenmenin değerlendirilmesi alt konuları yer almaktadır. Öğretim içeriği kategorisi; a-Finansal muhasebe; b-Denetim; c-Etik; d-Vergilendirme; e-Yönetim Muhasebesi; f-Muhasebe bilgi sistemleri özel konularından oluşmaktadır. Eğitim 
teknolojisinde; a-Teknoloji tabanlı öğrenme ve değerlendirme; b-Teknoloji ve müfredat sorunları yer almaktadır. Öğrenci ve öğretim üyesi konuları kategorisi ise; a-Öğrenci becerileri ve özellikleri; b-Akademik ana dal ve kariyer sorunları; c-Öğrenme yaklaşımları; dAkademik sahtekârlık özel konularından oluşmaktadır. Fakülte odaklı ampirik çalışmanın konuları da; a-Araştırma; b-Öğretim; c-İş piyasası; d-İdari konuları kapsamaktadır.

Öğrencilerin öğrenmeye yönelik yaklaşımlarını ele alan çalışmalar incelendiğinde 2000'li yılların başlangıcında yayınlanan makaleler, öğrenciler tarafından kullanılan öğrenme yaklaşımlarının belirlenmesi ve ölçülmesine odaklanmıştır (Adler vd., 2004:215). İlk araştırmalar, öğrenme stilleri ve mesleki nitelikler, cinsiyet, yaş ve akademik düzey gibi öğrenci özelliklerindeki farklılıklara yönelik iken (Duff, 1999: 100), bazı yazarlar ise ögrenme yaklaşımları ile öğrenci performansı arasındaki ilişkiyi incelemişlerdir (Davidson, 2002 , Jackling, 2005, Paver ve Gammie, 2005 ).

Geiger ve Ogilby (2000), öğrencilerin ilk muhasebe dersi ile ilgili algılarını ve bu algıların muhasebenin ana dal olarak seçilmesiyle nasıl ilişkili olduğunu incelemişlerdir. Sonuçlar muhasebenin bir ana dal olarak seçilmesine yönelik kararın, ilk dersteki performans ve bireysel eğitmenlere bağlı olduğunu, ancak ilk dersle ilgili algı değişikliklerine bağlı olmadığını göstermektedir. Wrong, Cooper ve Dellaportas (2003), iki Avustralya üniversitesindeki Çinli öğrencilerin Avustralya muhasebe eğitim programındaki öğrenme deneyimleriyle ilgili görüşlerini ortaya çıkarmak ve anlamak için keşif niteliğinde bir çalışma tasarlamışlardır. Sonuçta öğretmenlerin coşkusu, bağlılığı, sunum becerileri ve öğrencilerin beklentileri ile ilgili konular da öğrenci algılarını etkileyen önemli faktörler olarak ortaya çıkmıştır.

Clinton ve Kohlmeyer (2005), muhasebe eğitiminde işbirlikli öğrenme pedagojisinde grup sınavlarının muhasebe öğrencilerinin performansı ve öğrenme motivasyonu üzerindeki etkisini araştırmışlardır. Araştırma ile öğrencilerin işbirlikli olmayan öğrenme bağlamına kıyasla işbirlikli öğrenme bağlamında öğrenmek için daha büyük bir motivasyon sergiledikleri belirlemiştir. Grup üyelerini eğitmenin seçmesi yada öğrencilerin grup üyelerini kendilerinin seçmesine izin verilmesi halinde iki grup arasında performans farkı olmadığ ortaya konulmuştur.

Chen vd. (2010), bir muhasebe kursunda maliyet muhasebesi dersini alan öğrencilerin çevrimiçi ve geleneksel ara sınavlarda grup dinamiklerinin etkililiği ve algılarını araştırmışlardır. Araştırmanın çıkarımları şunlardır: i- Grup çalışması geleneksel bir sınıfta daha etkili olarak algılanmıştır; ii- grup çalışması için, dört öğrencilik gruplar uygundur ve iiiçevrimiçi öğrencilerin grup ödevlerinde bir çaba dengesizliği algılanmaktadır. Genel olarak, anket sonuçları, kurstaki maliyet muhasebesi dersinin sunum yönteminden ziyade, kursun geleceğe yönelik tasarımı üzerinde etkisini ortaya koymaktadır.

Bandura ve Lyons (2012) öğretim üyesi-öğrenci ilişkisinde profesörlerin onlara nasıl baktığına ilişkin öğrenci algılarını incelemiştir. Bir profesörün fakülte-öğrenci etkileşimini nasıl olumlu etkileyebileceğine ve bunu yaparken öğrenmeyi nasıl teşvik edebileceğine dair öğrencinin bakış açısına ilişkin bir miktar içgörü sağlanmıştır. Góis ve Brás (2013) Portekiz'de yüksek lisans öğrencilerinin muhasebeyi nasıl algıladıkları ve Bologna Süreci uygulaması sonrası muhasebe dersi boyunca bu algının nasıl geliştiğini incelemişlerdir. Ayrıca öğrencilerin algılarını etkileyen faktörleri (yaş, cinsiyet, iş deneyimi, kurum) ve 
algıların öğrenci performansını etkileyip etkilemediğini belirlemeye çalışmışlardır. Çalışma sonunda; erkek öğrencilerin kız öğrencilerden daha iyi performans gösterdiği belirlenmiştir. Genel olarak öğrencilerin muhasebeye ilişkin algıları ile muhasebe dersindeki performansları (notları) arasında bir ilişkiyi desteklemediği görülmüştür.

Öğrencilerin öğrenmeye yönelik yaklaşımları, öğrenme kavramları, motivasyonel yönelimler ve öğrenmenin düzenlenmesi gibi öğrencilerin öğreniminin diğer bazı yönleriyle bağlantılıdır (Heikkila ve Lonka, 2006). McDowall vd. (2015) öğrencinin öğrenmesini etkileyen bağlamsal ve çevresel faktörlerin bir analizi yapılarak öğretim kalitesinde, öğrenci beklentileri ve öğrenci motivasyonlarının öğrenci çıktıları ile ilişkili olduğu belirlenmiştir. Teixeira vd. (2015), Portekizli muhasebe öğrencilerinin güdülerini, beklentilerini ve yükseköğrenime istekli olmalarını incelemişlerdir. Sonuçlar, muhasebe öğrencilerinin muhasebe öğrenimine muhasebe olmayan öğrencilere göre daha fazla değer verdiğini, ancak diğer öğrencilerden bağımsız olarak çalışmaya daha az hazır olduklarını göstermektedir.

Costa vd. (2016), Portekizli muhasebe öğrencilerinin bir muhasebe kursuna etik algılarında cinsiyet, yaş, iş deneyimi ve etik gibi değişkenlerin etkisini incelemişlerdir. Araştırma bulguları Portekizli muhasebe öğrencilerinin etik algılarının cinsiyet, yaş, iş deneyimi veya bir etik dersi alıp almadığıyla ilişkili olmadığını göstermiştir. Apak (2020), ön lisans öğrencilerinin muhasebe derslerine yönelik tutumlarını incelemiş ve üniversite öncesi lise eğitiminde muhasebe dersi almış öğrencilerin muhasebe derslerine yönelik tutum ortalamalarının daha olumlu olduğu sonucuna ulaşmıştır.

\section{ARAŞTIRMA METODOLOJÍSI}

\subsection{Araştırma Modeli ve Hipotezler}

Bu çalışma kullandığı yöntem açısından tanımlayıcı araştırma sınıfında yer almaktadır. Endüstri Mühendisliği öğrencilerinin maliyet muhasebesi dersine ve dersi veren öğretim üyesine yönelik algıları belirlenmeye çalışılmıştır. Arıkan (2000) tarafından yapılan bir çalışmada, orijinal verilerin toplanması için geliştirilmiş yöntemlerin uygulandığ çalışmalar, ampirik çalışma olarak ifade edilmektedir. Değişkenler arasında ilişki analizleri de yapıldığında araştırma aynı zamanda açıklayıcı özelliğe sahip olmaktadır (Clark vd.,1998:9).

Muhasebe alanı dışındaki öğrencilerin maliyet muhasebesi hakkındaki algıları üzerine literatürde bir çalışma bulunmadığından, keşifsel bir çalışma, yararlı bir yol olarak çeşitli avantajlar sunmaktadır. Cooper ve Schindler (1998)'e göre, keşif amaçlı olan bu tür çalışmalar, özellikle araştırmacıların çalışma sırasında karşılaşacakları problemler hakkında net bir fikre sahip olmadığ 1 durumlarda yararlıdır. Keşif yoluyla, araştırmacılar kavramları daha net bir şekilde geliştirir, öncelikleri belirler, operasyonel tanımlar geliştirir ve nihai araştırma tasarımını iyileştirir.

Keşif çalışmalarında araştırmacılar, ayrıntılı bir araştırma tasarımı için kılavuz olarak kullanılabilecek bir dizi yardımcı araştırma sorusu tanımlar (Góis ve Brás, 2013: 41; Cooper ve Schindler, 1998). 
Araştırmanın hipotezleri ve modeli aşağıdaki gibidir.

$\mathrm{H}_{1}$ : Öğrencilerin, öğretim üyesinin yetkinliğine ilişkin algısı ile derse ilişkin algısı arasında anlamlı bir ilişski vardır.

$\mathrm{H}_{2}$ : Öğrencilerin, öğretim üyesinin etkileşime ilişkin algısı ile derse ilişkin algısı arasında anlamlı bir ilişki vardır.

$\mathrm{H}_{3}$ : Öğrencilerin, öğretim üyesinin ders işleyişine ilişsin algısı ile derse ilişkin algısı arasında anlamlı bir ilişki vardır.

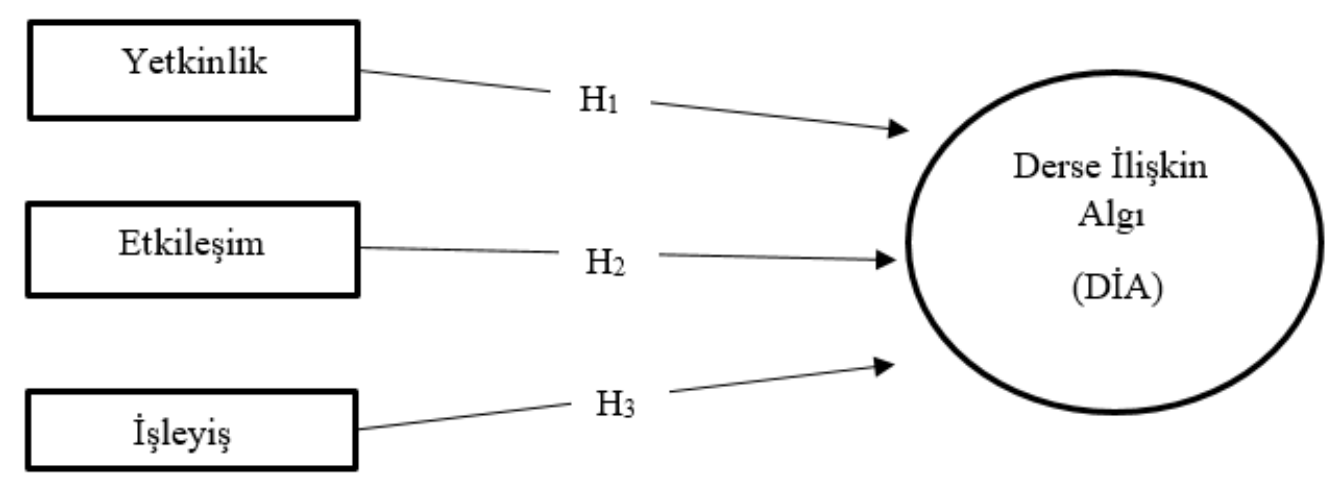

Şekil 3. Araştırmanın Modeli

Bu bölümde araştırmanın amacı ve önemi, evren ve örneklem, veri toplama yöntemi ve analizler ile sinırlılıklar yer almaktadır.

\subsection{Araştırmanın Amacı ve Önemi}

Araştırmanın amacı, maliyet muhasebesi dersini alan Mühendislik Fakültesi Endüstri Mühendisliği Bölümü öğrencilerinin derse ve dersi veren öğretim üyesine yönelik algılarını ortaya koymak ve bu algılar arasındaki ilişkileri belirlemektir.

Çalışmanın önemi; ilgili çalışma yurt içi ve yurt dışında muhasebe ve işletme bölümü dışında yer alan mühendislik fakültesi öğrencilerine ilk defa uygulanıyor olmasıdır. Bu bölümlerde yapılan uygulama sonuçları ile karşılaştırma olanağı sağlanmıştır. Ayrıca bu çalışma, ilgili paydaşlardan öğrencilere, araştırmacılara ve maliyet muhasebesi dersini veren akademisyenlere dersi planlama, dersin işleyişi ve ders materyalleri hakkında yol gösterici olabilecektir.

\subsection{Evren ve Örneklem}

Araştırma evrenini, Kütahya Dumlupınar Üniversitesi Mühendislik Fakültesi Endüstri Mühendisliği Bölümü’nde maliyet muhasebesi dersini alan öğrenciler oluşturmaktadır. 20202021 eğitim ve öğrenim yılı güz yarı döneminde söz konusu derse kayıtlı toplam 180 öğrenci bulunmaktadır. Tüm öğrencilere internet üzerinden anket verilmiş olmakla birlikte anket formunu doldurarak sisteme yüklemeyen öğrenciler kapsam dışı tutulmuştur. Çünkü veri 
toplamanın ön koşulu gönüllülük esasıdır. Araştırmaya katılma konusunda istekli olan 139 öğrenci araştırmanın örneklemini oluşturmaktadır.

\subsection{Veri Toplama Yöntemi ve Analizler}

Araştırmada veri toplama yöntemi olarak, öğrencilerin maliyet muhasebesi dersi ve dersi veren öğretim üyesine yönelik algılarını ölçtüğü düşünülen soru formlarından oluşan, anket tekniği kullanılmıştır.

Kullanılan anket formu üç bölümden oluşmaktadır. Birinci bölümde öğrencilerin demografik özelliklerini belirlemeye yönelik ifadeler; ikinci bölümde öğrencilerin maliyet muhasebesi dersine ilişkin algılarını (DİA) belirlemeye yönelik ifadeler ve üçüncü bölümde ise öğrencilerin maliyet muhasebesi dersini veren öğretim üyesine (DVÖÜ) ilişkin algılarını belirlemeye yönelik ifadeler yer almaktadır. Araştırmada kullanılan DİA ölçeği, Krathwohl vd.'nin sınıflandırma çalışmasından uyarlanarak Geiger ve Ogilby (2000) tarafindan geliştirilmiş ölçekten yararlanılarak tasarlanmıştır. Araştırmada kullanılan bir diğer ölçek olan DVÖÜ ölçeği ise Abdullah (2006) tarafından yükseköğretim için tasarlanan, Parasuraman vd. (1985) hizmet kalitesinin ölçmek için öne sürmüş oldukları ölçekten yararlanılmıştır.

Araştırmada kullanılan ölçeklerin yapı geçerliğini sağlamak için faktör analizi yapılmış; güvenirlik için de Croanbach Alpha Yöntemi kullanılmıştır. Verilerin değerlendirilmesinde frekans, yüzde, aritmetik ortalama, standart sapma değerleri alınmış ve yorumlanmıştır. Hipotezleri test etmek amacıyla korelasyon analizi yapılmıştır.

Değerlendirme, öğrenme deneyiminin merkezinde yer alır. Öğrencilerin nasıl değerlendirildiği müfredat anlayışlarını şekillendirerek ilerleme yeteneklerini belirlemektedir. Değerlendirme ve geri bildirim, eğitim kurumlarının iş yüklerinin önemli bir bölümünü oluşturarak, artan sayılar, azalan bütçeler ve daha yüksek öğrenci beklentileri ile endişe konusu olmaya devam etmektedir. Çalışmaları hakkında aldıkları geri bildirimlerden öğrencilerin memnuniyetsizliği, çoğu kurumun, öğrenci iş yükünde önemli artışlar olmadan ele almak istediği bir konudur (Ferrell, 2012:3).

\subsection{Sinırlılıklar}

Araştırmanın en büyük sınırlılığı muhasebe eğitimi araştırmalarının tasarımlarının bir teoriye dayalı olmaması, teorik temel eksikliğidir. Bir diğer sınırlama ise çalışmanın yapıldığ dönemde, dünyanın dört bir yanındaki ülkelerde sağlık, ekonomi, yaşam ve eğitimde köklü bir değişikliğe yol açan COVID-19 pandemisi nedeniyle, eğitimin geleneksel yüz yüze sınıf ortamında eğitim yerine uzaktan eğitim olarak sağlanıyor olmasıdır. Ayrıca yapılan bu çalışma coğrafi olarak Kütahya Dumlupınar Üniversitesi Mühendislik Fakültesi Endüstri Mühendisliği Bölümü'nde 2020-2021 eğitim ve öğretim yılı güz yarıyılında maliyet muhasebesi dersi alan öğrenciler ile sınırlıdır. Öğretim elemanlarının değerlendirilmesinde öğrenci tutumları belirlenirken bir öğrencinin bir hocayı sevmesi ama muhasebeyi sevmemesi mümkündür. 


\section{BULGULAR}

Bu bölümde, araştırma kapsamında elde edilen verilerle ilgili bulgular yer almaktadır.

\subsection{Araştırmaya Katılan Öğrencilerin Demografik Özelliklerine İlişkin Bulgular}

Araştırmaya katılan öğrencilerin \%67,6'sı kadın, \%32,4'ü erkek; \%45,3'ü 21 yaş, $\% 25,2$ 'si 22 yaş, \%14,4'ü 23 yaşında ve \%15,1'i de 24 ve üzeri yaştadır ve öğrencilerin tamamına yakını $(\% 98,6)$ ise Türkiye Cumhuriyeti vatandaşıdır. Öğrenim durumu açısından öğrencilerin \%60,4'ü normal öğretim, \%39,6'sını ikinci öğretim öğrencileri oluşturmaktadır. Endüstri Mühendisliği Bölümü üçüncü sınıf güz dönemi dersi olan maliyet muhasebesi dersini ilk defa alan (\%87,1) 3. sınıf öğrencileri oluştururken, \%1.4'nü alttan alan üst sınıf ögrencileri oluşturmaktadır. Kalan 11,4'lük kısmı ise işletme ve muhasebe bölümlerinde pek sık rastlanılmayan yüksek not ortalamasına sahip olan ve üstten ders almaya hak kazanan 2 . sınıf öğrencileri oluşturmaktadır.

Tablo 1. Demografik Bilgiler

\begin{tabular}{llcc}
\hline & & $\mathrm{n}$ & $\%$ \\
\hline \multirow{2}{*}{ Cinsiyet } & Kadın & 94 & 67,6 \\
& Erkek & 45 & 32,4 \\
\hline \multirow{3}{*}{ Yaş } & 21 yaş & 63 & 45,3 \\
& 22 yaş & 35 & 25,2 \\
& 23 yaş & 20 & 14,4 \\
& 24 ve üzeri yaş & 21 & 15,1 \\
\hline \multirow{2}{*}{ Uyruk } & T. C. & 137 & 98,6 \\
& Yabancı & 2 & 1,4 \\
\hline \multirow{2}{*}{ Ŏğrenim } & Normal öğretim & 84 & 60,4 \\
& İkinci öğretim & 55 & 39,6 \\
\hline \multirow{2}{*}{ Sinıf } & 2. sinıf & 16 & 11,5 \\
& 3. sinıf & 121 & 87,1 \\
& 4. sinıf & 2 & 1,4 \\
\hline
\end{tabular}

\subsection{Faktör Analizlerine İlişkin Bulgular}

Faktör analizine göre öğrencilerin maliyet muhasebesi dersini veren öğretim üyesine yönelik algılarıyla ilgili ifadeler toplam üç alt boyutta incelenmektedir. $\mathrm{Bu}$ boyutlar "yetkinlik", "etkileşim" ve "işleyiş" olarak isimlendirilmiştir. Söz konusu boyutlar toplam varyansın \%64,869’unu açıklamaktadır. 
Tablo 2. Öğrencilerin Dersi Veren Öğretim Üyesine İlişkin Algıları(DVÖÜ)

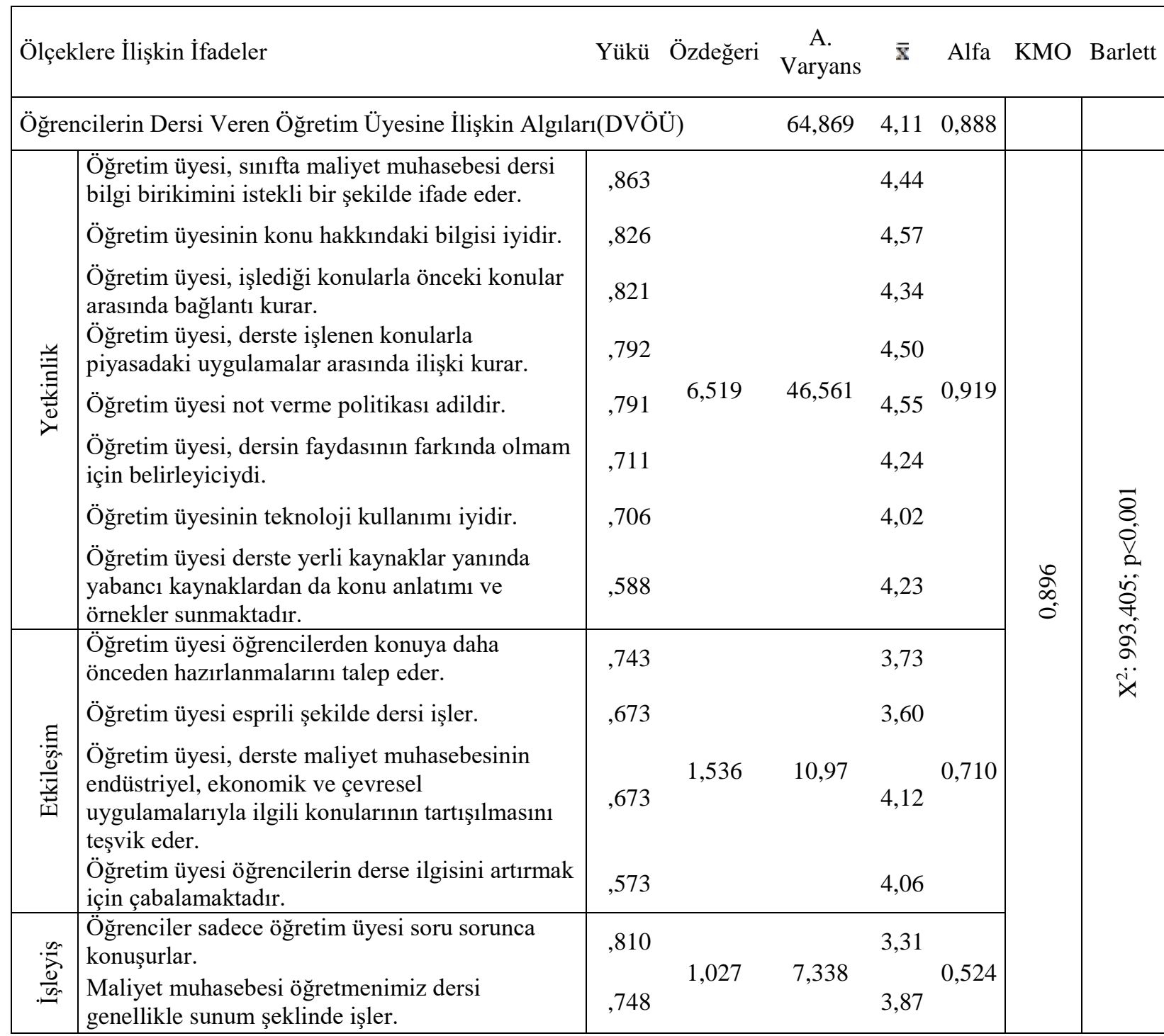

Ölçeğin orijinalinde yer alan “Öğretim üyesi arkadaş canlısıdır”, “Öğretim üyesinin dersteki tutumu katıdır" ve “Öğretim üyesi, bilgiyi dĕ̆erlendirmeleri için ögrrencileri cesaretlendirir" ifadeleri yap1 geçerliğini ve güvenirliği düşürdüklerinden dolayı ölçekten çıkarılmıştır. Buna göre dersi veren öğretim üyesinin yetkinlik anlamında iyi olduğu söylenebilir. Dersin işlenişiyle ilgili ifadelere verilen cevapların ortalamalarının nispeten düşük olması çalışmanın uzaktan eğitim döneminde yapılmış olmasıyla ilgili olabilir.

Öğretim üyesine yönelik algı ölçeğinin güvenirliğini (iç tutarlılık) sınamak için güvenirlik hesaplamalarında en çok tercih edilen yöntem olan Cronbach's Alpha ( $\alpha$ ) yöntemi kullanılmıştır. Öğretim üyesine yönelik alg1 ölçeğinin içsel tutarlılık katsayısı $\alpha=0,888$ olarak hesaplanmıştır. Özdamar (2004)'e göre bu oran ölçeğin yüksek derecede güvenilir olduğunu göstermektedir. 
Maliyet muhasebesi dersine yönelik öğrenci algıları ölçeğine ilişkin yapılan faktör analizine göre derse ilişkin alg1 tek boyutta toplanmıştır. Derse ilişkin alg1 olarak isimlendirilen bu boyut toplam varyansın \%55,498'ini açıklamaktadır.

Tablo 3. Öğrencilerin Derse İlişkin Algıları(DİA)

\begin{tabular}{|c|c|c|c|c|c|c|c|c|}
\hline \multicolumn{2}{|c|}{ Ölçeklere İlişkin İfadeler } & Yükü & Özdeğeri & $\begin{array}{c}\text { A. } \\
\text { Varyans }\end{array}$ & $\overline{\mathrm{x}}$ & Alfa & KMO & Barlett \\
\hline \multicolumn{5}{|c|}{ Öğrencilerin Derse İlişkin Algıları(DİA) } & \multicolumn{4}{|l|}{4,00} \\
\hline \multirow{6}{*}{ 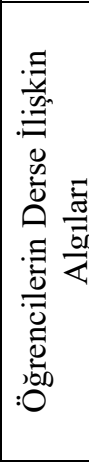 } & $\begin{array}{l}\text { Bu dersteki iyi bir performans kişisel } \\
\text { olarak memnuniyet vericiydi. }\end{array}$ & ,856 & \multirow{6}{*}{3,330} & \multirow{6}{*}{56,498} & 4,16 & \multirow{6}{*}{0,809} & \multirow{6}{*}{$\begin{array}{l}8 \\
\infty \\
0 \\
0\end{array}$} & \multirow{6}{*}{ 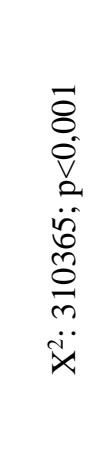 } \\
\hline & $\begin{array}{l}\text { Bu dersin kariyerimi geliştirmeme } \\
\text { vardımcı olacağına inanmaktayım. }\end{array}$ & ,814 & & & 4,12 & & & \\
\hline & $\begin{array}{l}\text { Bu ders konuları üst sınıftaki diğer ders } \\
\text { konularını işlemek için çok önemliydi. }\end{array}$ & ,758 & & & 3,93 & & & \\
\hline & $\begin{array}{l}\text { Bu (maliyet muhasebesi ) konuda bilgi } \\
\text { alanım çok arttı. }\end{array}$ & ,757 & & & 4,00 & & & \\
\hline & Bu dersten keyif aldım. & ,703 & & & 3,87 & & & \\
\hline & $\begin{array}{l}\text { Bu derste her zaman iyi bir puan almak } \\
\text { için motive oldum. }\end{array}$ &, 540 & & & 3,91 & & & \\
\hline
\end{tabular}

Ölçeğin orijinalinde yer alan "Bu derse diğer derslerden daha fazla zaman harcadım”, "Bu dersin konularını ögrenmek gerçekten zordu” ve "Bu ders ve konuları sıkıcıydı" ifadeleri yap1 geçerliğini ve güvenirliği düşürdüklerinden dolayı ölçekten çıkarılmıştır.

Derse ilişkin algı ölçeğinin içsel tutarlılık katsayısı $\alpha=0,809$ olarak hesaplanmıştır. Özdamar (2004)'e göre bu oran, ölçeğin yüksek derecede güvenilir olduğunu göstermektedir.

\subsection{Korelasyon Analizine İlişkin Bulgular}

Öğrencilerin maliyet muhasebesi dersine yönelik algıları ile dersi veren öğretim üyesine yönelik algılarının alt boyutları arasındaki ilişkiyi ortaya koymak amacıyla korelasyon analizi yapılmıştır.

Tablo 4. Korelasyon Analizi Sonuçları

\begin{tabular}{lcccccc}
\hline $\mathrm{n}=139$ & $\mathrm{x}$ & s.s. & DİA* & Yetkinlik & Etkileşim & İşleyiş \\
\cline { 2 - 6 } DİA* & 4 & 0,614 & - & & & \\
Yetkinlik & 4,36 & 0,638 &, $744^{* *}$ & - & & \\
Etkileşim & 3,88 & 0,641 &, $493^{* *}$ &, $594^{* *}$ & - & \\
İşleyiş & 3,60 & 0,889 &, $318^{* *}$ &, $370^{* *}$ & 0,111 & -
\end{tabular}

Notlar: * DİA: Derse İlişkin Alg1

** Korelasyon .01 düzeyinde anlamlıdır. 
Yapılan korelasyon analizine göre yetkinlik ile DİA arasında istatistiksel olarak anlamlı ve pozitif yönlü kuvvetli bir ilişki $(r=, 744 ; p<0,01)$ olduğu tespit edilmiştir. Buna göre öğrencilerin öğretim üyesinin yetkinliğine ilişkin algıları arttıkça derse ilişkin algılarının da artacağını söylemek mümkündür. $\mathrm{Bu}$ durumda " $H_{1}$ : Öğrencilerin, ögrretim üyesinin yetkinliğine ilişkin algısı ile derse ilişkin algısı arasında anlamlı bir ilişki vardır” hipotezi kabul edilmiştir.

Korelasyon analizinde DİA ile etkileşim arasında istatistiksel olarak anlamlı ve pozitif yönlü orta düzeyde bir ilişki $(r=, 493 ; p<0,01)$ bulunmuştur. Buna göre öğrencilerin, dersi veren öğretim üyesinin etkileşimine ilişkin algıları arttıkça derse ilişkin algılarının da artacağ söylenebilir. Bu durumda " $\mathrm{H}_{2}$ : Öğrencilerin, öğretim üyesinin etkileşime ilişkin algisı ile derse ilişkin algısı arasında anlamlı bir ilişki vardır” hipotezi kabul edilmiştir.

Korelasyon analizine göre işleyiş ile DİA arasında istatistiksel olarak anlamlı ve pozitif yönlü orta düzeyde bir ilişki $(\mathrm{r}=, 493 ; \mathrm{p}<0,01)$ olduğu ortaya konulmuştur. Buna göre öğrencilerin, dersi veren öğretim üyesinin ders işleyişine yönelik algıları arttıkça derse ilişkin algılarının da artacağını söylemek mümkündür. $\mathrm{Bu}$ durumda " $H_{3}$ : Öğrencilerin, öğretim üyesinin ders işleyişine ilişkin algısı ile derse ilişkin algısı arasında anlamlı bir ilişki vardır", hipotezi kabul edilmiştir.

\section{SONUÇ}

Araştırmada öğrencilerin dersi veren öğretim üyelerine yönelik algıları incelendiğinde, öğretim üyesinin yetkinliğine yönelik algıların, etkileşim ve işleyiş algılarından daha yüksek olduğu görülmektedir. Mesleki yetkinliğin özellikleri göz önüne alındığında dersi veren öğretim üyesinin bilgi ve tutum yönünden öğrenciler tarafindan olumlu algılandığı söylenebilir.

Öğretim üyesiyle ilgili etkileşim algısına bakıldığında, “Öğretim üyesi esprili şekilde dersi işler” ifadesine öğrencilerin daha az katıldıkları görülmektedir. Bu durum öğrencilerin dersleri daha eğlenceli bir şekilde geçirmek istemelerinin bir sonucu olabilir. Bununla birlikte, dersin uzaktan eğitimle gerçekleştiriliyor olması, derslerde hem öğrencilerin hem de öğretim üyesinin kameralarının kapalı olması, uzaktan eğitimde süre kısıtıyla birlikte dersle ilgili konuların verilmesinin daha uygun olması gibi nedenlerle, derslerin daha eğlenceli hale getirilmesi pek mümkün görünmemektedir.

Dersi veren öğretim üyesine yönelik en olumsuz alg1 "Öğrenciler sadece öğretim üyesi soru sorunca konuşurlar" ifadesidir. Bu durumu aslında öğrencilerin iletişim sorunlarıyla açıklamak daha uygundur. Çünkü dersi alan öğrencilerin birçoğu Z kuşağıdır. Tuncer (2016) tarafından yapılan bir araştırmaya göre, $Z$ kuşağı genel olarak internete bağımlı, psikografik ve karakteristik gelişimleri devam eden, çevre ile olumlu ve etkili ilişkiler kurmak için iletişim becerileri yetersiz olarak görülen bireylerdir (Tuncer, 2016: 34).

Öğrencilerin maliyet muhasebesi dersine ilişkin algıların incelendiğinde " $\mathrm{Bu}$ dersin kariyerimi geliştirmeme yardımcı olacağına inanmaktayım” ifadesine olumlu görüş bildirmişlerdir. Ayrıca Endüstri mühendisliği alanındaki lisansüstü tez çalışmalarında maliyet muhasebesi konusu hatırı sayılır bir orana sahiptir. Bu durum öğrencilerin, kariyerlerini ister 
sektörde isterse de akademik olarak sürdürsün maliyet muhasebesi dersinin öneminin farkında olduklarını göstermektedir.

Araştırmanın temel çıkış noktasını oluşturan değişkenler olan, öğrencilerin öğretim üyesine yönelik algıları ile derse ilişkin algıları arasında anlamlı bir ilişki olduğu ortaya konulmuştur. Bu sonuç konuyla ilgili yapılan bazı çalışmaların sonuçlarıyla örtüşmektedir. Örneğin; Geiger ve Ogilby (2000) tarafından yapılan çalışmada, muhasebe öğrencilerinin ders seçiminin bireysel eğitmenlere bağlı olduğu, Wrong vd. (2003) tarafından yapılan çalışmada, Çinli öğrencilerin Avustralya muhasebe eğitim programında öğrenme deneyimlerinin öğretmen coşku ve becerilerine bağlı olduğu, Bandura ve Lyons'un (2012) Portekiz'de yüksek lisans öğrencilerinin muhasebeyi algılamalarını öğretim üyesinin teşvik ettiği gibi sonuçlar elde edilmiştir.

Öğretim üyesine yönelik algıların alt boyutları ile derse ilişkin algı arasındaki ilişkiler incelendiğinde, öğretim üyesinin yetkinliğine yönelik algının öğrenciler tarafından daha çok dikkate alındığı tespit edilmiştir. Buna göre öğrencilerin, ders aldıkları öğretim üyelerinin etkileşim ve ders işleme metotlarından ziyade yetkinliklerine daha çok önem verdikleri söylenebilir.

Konuyla ilgili bundan sonraki araştırmalarda bu değişkenlerin öğrencilerin ders başarılarına etkisi olup olmadığı ölçülebilir. Araştırmanın pandemiden dolayı uzaktan eğitim yapılan bir dönemde gerçekleştirilmesi önemli bir farklılıktır. Yüz yüze eğitim başladıktan sonra farklı üniversiteler ve farklı bölümlerdeki öğrencilerin muhasebe ile ilgili derslere yönelik algıları ortaya konulabilir. Yapılacak bu çalışmalar literatüre katkı sunmakla birlikte derslerin planlamalarını yapan yöneticilere ve dersi veren öğretim üyelerine yol gösterici olabilir. Ayrıca bu çalışma, öğrencilerin muhasebe algılarını etkilemede öğretim üyesinin önemi hakkında deneysel kanıtlar sağlamaktadır. Eğitimciler olarak, gelecekteki maliyet muhasebesi profesyonellerinin başarılı olmaları için ihtiyaç duydukları yetkinliklere sahip olmasını sağlayarak zorlukların üstesinden gelebilmeleri için firsatlar sunulabilir.

\section{KAYNAKLAR}

AACE, Association for the Advancement of Cost Engineering (2021), https://web.aacei.org/about-aace, (08.02.2021).

Abdullah, Firdaus (2006), "Measuring Service Quality in Higher Education: HEdPERF Versus SERVPER”. Marketing Intelligence \& Planning, pp.24, 31-47.

Adler, Ralph W.- Whiting, Rosalind H.- Williams, Kate Wynn (2004), “Student-Led and Teacher-Led Case Presentations: Empirical Evidence About Learning Styles in an Accounting Course”, Accounting Education, 13(2), pp.213-229.

Apak, İbrahim (2020), “Ön Lisans Öğrencilerinin Muhasebe Derslerine Yönelik Tutumları Üzerine Bir Araştırma”, Sosyal Ekonomik Araştırmalar Dergisi, 20(40), ss.227-236.

Apostolou, Barbara - Dorminey, Jack W.- Hassell, John M. - Rebele, James E. (2016), “Analysis of Trends in the Accounting Education Literatüre (1997-2016)", Journal of Accounting Education, 41, pp.1-14. 
Bandura, Randall P. - Lyons, Paul (2012), “Instructor Care and Consideration Toward Students-What Accounting Students Report: A Research Note”, Accounting Education: An International Journal, 21(5), pp.515-527.

Bui, Bihn - Porter, Brenda (2010), “The Expectation-Performance Gap in Accounting Education: An Exploratory Study”, Accounting Education: an International Journal, 19(1-2), pp.23-50.

ICAI. The Institute of Cost Accountants of India (2018), Cost Accounting Intermadiate, CMA Bhawan, Kolkata, India.

Booth, Peter - Luckett, Peter - Mladenovic, Rosina (2010), “The Quality of Learning in Accounting Education: The Impact of Approaches to Learning on Academic Performance”, Accounting Education, 8(4), pp.277-300.

Chen, Clement C. - Jones, Keith T. - Moreland, Keith (2010), "Virtual Groups in a Cost Accounting Course: Group Dynamics, Outcomes, and Participant Satisfaction", Advances in Accounting Education, 11, pp.153-170.

Clinton, B. Douglas - Kohlmeyer III, James M. (2005), “The Effects of Group Quizzes on Performance and Motivation to Learn: Two Experiments in Cooperative Learning”, Journal of Accounting Education, 23(2), pp.96-116.

Cooper, Donald R. - Schindler, Pamela S. (1998), Business Research Methods, McGraw-Hill International Editions, 6th Edition.

Costa, Alberto J.- Pinheiro, Margarida M. - Ribeiro, Mariana S. (2016), "Ethical Perceptions of Accounting Students in a Portuguese University: The Influence of Individual Factors and Personal Traits”, Accounting Education, 25(4), pp.327-348.

Davidson, Ronald A. (2002), "Relationship of Study Approach and Exam Performance”. Journal of Accounting Education, 20(1), pp.29-44.

Duff, Angus. (1999), “Access Policy and Approaches to Learning”, Accounting Education, 8(2), pp.99-110.

Ferrell, Gill (2012), “A View of The Assessment and Feedback Landscape: Baseline Analysis of Policy and Practice From the JISC Assessment \& Feedback Programme", JISC AF Baseline Report. www.jisc.ac.uk/assessresource, (02.02.2021).

Geiger, Marshall A. - Ogilby, Suzanne M. (2000), “The First Course in Accounting: Students' Perceptions and Their Effect On The Decision to Major in Accounting”, J. of Acc. Ed. 18, pp.63-78.

Góis, Cristina - Brás, Filomena Antunes (2013), “In The Aftermath of the Bologna Process: Exploring the Master Students' Perceptions on Accounting in Two Portuguese Higher Education Institutions”, The Spanish Journal of Accounting, Finance and Management Education, 4, pp.34-55. 
Guo, Ken H. (2018), “The Odyssey of Becoming: Professional Identity and Insecurity in the Canadian Accounting Field”, Critical Perspectives on Accounting, 56, pp.20-45.

Heikkila“, Annamari - Lonka, Kirsti (2006), "Studying in Higher Education: Students' Approaches to Learning, Self-Regulation, and Cognitive Strategies”, Studies in Higher Education, 31(1), pp.99-117.

Herbert, Ian P.- Rothwell, Andrew T.- Glover, Jane L. - Lambert, Stephanie A. (2020), “Does the Changing World of Professional Work Need a New Approach to Accounting Education?”, Accounting Education, ss.1-25. DOI: 10.1080/09639284.2020.1827446

Krathwohl, David R.- Bloom, Benjamin S. - Masia, Bertram B. (1964), Taxonomy Educational objectives: The Classication of Educational Goals. Handbook II: Affective Domain. New York: David McKay Company, Inc.

McDowall, Tracey - Jackling, Beverley - Natoli, Riccardo (2015), "Relationships Between Vocational Interests and Learning Approaches to Advance The Quality of Student Learning in Accounting”, Accounting Education, 24(6), pp.498-513.

Mourik, Greg van - Wilkin, Carla (2019), "Educational Implications and the Changing Role of Accountants: a Conceptual Approach to Accounting Education”, Journal of Vocational Education \& Training, 71(2), pp.312-335.

Özdamar, Kazım (2004), Paket Programlarla İstatistiksel Veri Analizi. Kaan Kitabevi. Eskişehir.

Parasuraman, A Parsu - Zeithaml, Valarie A. - Berry. Leonard L. (1985), “A Conceptual Model of Service Quality and Its Implications for Future Rresearch”, Journal of Marketing, 49, pp.41-50.

Paver, Brenda - Gammie, Elizabeth (2005), “Constructed Gender, Approach to Learning and Academic Performance”, Accounting Education, 14(4), pp.427-444.

Rao, Narayana - Srivastava, DK. (2009), Industrial Engineering is Human Effort Engineering and System Efficiency Engineering. Industrial Engineering Knowledge Center, http://nraoiekc.blogspot.com/2012/09/total-cost-industrial-engineering.html. (12.02.2021).

Sithole, Seedwell T.M. (2017), “Instructional Strategies and Students' Performance in Accounting: An Evaluation of Those Strategies and The Role of Gender”, Accounting Education, 27(4), pp.1-19.

Teixeira, Claudia - Gomes, Delfina - Borges, Janete (2015), “Introductory Accounting Students' Motives, Expectations and Preparedness for Higher Education: Some Portuguese Evidence”, Accounting Education, 24(2), pp.123-145.

Tuncer, M. Umut (2016), “Ağ Toplumunun Çocukları: Z Kuşağının Kişilerarası İletişim Becerilerinin Çok Boyutlu Analizi”. Atatürk İletişim Dergisi, 10 (Ocak), ss.33-45. 
Wong, Grace - Cooper, Barry J. - Dellaportas, Steven. (2015), “Chinese Students’ Perceptions of the Teaching in an Australian Accounting Programme- An Exploratory Study”, Accounting Education, 24(4), pp.318-340.

Yüksek Öğretim Kurulu Başkanlığı Ulusal Tez Merkezi, https://tez.yok.gov.tr/UlusalTezMerkezi/ (05.01.2021). 
